\title{
ANALISIS PENGARUH FINANCING TO DEPOSIT RATIO (FDR) TERHADAP PROFITABILITAS PERBANKANSYARIAH DI INDONESIA (Rasio Keuangan pada BUS dan UUS Periode 2008-2010)
}

\author{
Suryani $^{1}$
}

\begin{abstract}
This study aimed to (1) analyze the condition of Financing to Deposit Ratio (FDR) of Islamic Banking in Indonesia; (2) analyze the profitability of sharia banking in Indonesia; and (3) to analyze the influence of Financing to Deposit Ratio (FDR) of the profitability of sharia banking in Indonesia. This study took samples at Islamic banks in Indonesia including 11 Islamic Banks (BUS), 23 Business Units of Sharia Banking (UUS). The research data is from Islamic Banking Statistics published by Bank Indonesia from January 2008 until December 2010 (Financial Ratio Study to BUS and UUS period 2008-2010). The number of Islamic banks used is 34 banks. The technique uses simple linear regression analysis with the help of the program EVIEWS version 5.

The results of analysis is further illustrated as follows: First: Financing to Deposit Ratio (FDR) of sharia banking has an average of $103.65 \%$ during the year 2008, $89.70 \%$ in 2009 and 94.37\% in 2010. Overall, the average Financing to Deposit Ratio (FDR) in the three years is about 98.79\%. Second: Return on Asset (ROA) is one of the profitability ratio used to measure the effectiveness of the company in generating profit by leveraging its total asset. Based on the description of the variables, it shows the average Return on Asset (ROA) in 2008 is of $1.77 \%, 1.98 \%$ in 2009 and $1.74 \%$ in 2010. This result indicates that the average Return on Asset (ROA) in three years of observation is still above the prevailing bank. Third: The result of regression analysis indicates no significant of Financing to Deposit Ratio (FDR) for Return on Assets (ROA). The quantity $t$ count is 0.475 far below the t table 2.032. The result of study differs from the study of Adi Stiawan (2009), but supports the study of Nurkhosidah Siti (2010) and Yuliani (2007). This study shows no significant effect on bank profitability.
\end{abstract}

Keyword : Profitability, Return on Asset (ROA), Financing to Deposit Ratio (FDR), Indonesian Islamic Banking, Islamic Banking Statistics.

\section{A. PENDAHULUAN}

Sejak satu dekade terakhir di Indonesia telah diperkenalkan suatu sistem perbankan dengan metode pendekatan syariah Islam yang dapat menjadi perbankan alternatif bagi

\footnotetext{
${ }^{1}$ Dosen STAIN Malikussaleh Lhokseumawe
} 
masyarakat, khususnya bagi umat Islam. Gambaran suatu perbankan yang aman, terpercaya dan amanah serta terbebas dari riba sangat dirindukan oleh masyarakat.

Karakteristik sistem perbankan syariah yang beroperasi berdasarkan prinsip bagi hasil memberikan alternatif sistem perbankan yang saling menguntungkan bagi masyarakat dan bank, serta menonjolkan aspek keadilan dalam bertransaksi, investasi yang beretika, mengedepankan nilai-nilai kebersamaan dan persaudaraan dalam berproduksi dan menghindari kegiatan spekulatif dalam bertransaksi keuangan.

Perbankan syariah di Indonesia sendiri muncul pada tanggal 1 Mei 1992 yaitu sejak berdirinya Bank Muamalat Indonesia (BMI), hingga saat ini perkembangan perbankan syariah di Indonesia juga cukup menggembirakan. Perbankan syariah memasuki sepuluh tahun terakhir, pasca perubahan UU Perbankan yang ditandai dengan terbitnya UU No. 10/1998 tentang Perbankan, mengalami pertumbuhan dan perkembangan yang amat pesat. Perkembangan yang pesat itu terutama tercatat sejak dikeluarkannya ketentuan Bank Indonesia yang memberi izin untuk pembukaan bank syariah yang baru maupun pendiriaan Unit Usaha Syariah (UUS).

Industri perbankan menghimpun Dana Pihak Ketiga (DPK) yang merupakan simpanan pihak ketiga bukan bank dalam bentuk tabungan, giro dan simpanan bernilai, yang selanjutnya disalurkan kembali dalam nilai memperoleh profit. Salah satu bentuk penyaluran dana perbankan adalah berupa penyaluran kredit (dalam istilah bank umum) dan pembiayaan (dalam istilah bank syariah). Penyaluran dana pembiayaan baik dalam bentuk kredit ataupun pembiayaan kepada masyarakat baik individu maupun korporasi untuk berbagai peruntukan konsumsi, investasi, modal kerjadan lain-lain selanjutnya akan berpengaruh terhadap gerak roda sektor riil yang pada akhirnya dapat mempengaruhi pertumbuhan ekonomi.

Sebagai lembaga yang penting dalam perekonomian maka perlu adanya pengawasan kinerja yang baik oleh regulator perbankan. Salah satu indikator untuk menilai kinerja keuangan suatu bank adalah melihat tingkat profitabilitasnya. Hal ini terkait sejauh mana bank menjalankan usahanya secara efisien. Efisiensi diukur dengan membandingkan laba yang diperoleh dengan aktiva atau modal yang menghasilkan laba. Semakin tinggi profitabilitas suatu bank, maka semakin baik pula kinerja bank tersebut.

Profitabilitas bank-bank syariah tercermin pada Return on Asset (ROA) dan Return on Equity (ROE). Jika dibandingkan dengan rerata ROA-ROE bank konvensional (ROA=1,5\% dan $\mathrm{ROE}=15 \%$ ), hanya PT. Bank Syariah Muamalat Indonesia yang sudah berada dalam kuadran profitable.

Mengingat begitu pentingnya fungsi dan peranan perbankan syariah di Indonesia, maka pihak bank syariah perlu meningkatkan kinerjanya agar tercipta perbankan dengan prinsip syariah yang sehat dan efisien. Profitabilitas merupakan indikator yang paling tepat untuk mengukur kinerja suatu bank (Syofyan, 2002). Menurut Karya dan Rakhman, tingkat profitabilitas bank syariah di Indonesia merupakan yang terbaik di dunia diukur dari rasio laba terhadap asset (ROA), baik untuk kategori bank yang full fledge maupun untuk kategori Unit Usaha Syariah (Diah Aristya, 2010:8)

Return on Assets (ROA) digunakan untuk mengukur profitabilitas bank karena Bank Indonesia sebagai pembina dan pengawas perbankan lebih mengutamakan nilai profitabilitas suatu bank yang diukur dengan aset yang dananya sebagian besar dari dana simpanan masyarakat. Semakin besar ROA suatu bank, semakin besar pula tingkat keuntungan yang dicapai bank, dan semakin baik posisi bank tersebut dari segi penggunaan aset ${ }^{2}$.

Salah satu indikator yang digunakan untuk mengukur tingkat profitabilitas adalah ROA. ROA penting bagi bank karena ROA digunakan untuk mengukur efektifitas perusahaan dalam menghasilkan keuntungan dengan mamanfaatkan aktiva yang

2 Lukman Dendawijaya, Manajemen Perbankan, (Jakarta, Ghalia Indonesia, 2009), h. 118. 
dimilikinya. ROA merupakan rasio antara laba sesudah pajak terhadap total asset. Semakin besar ROA menunjukkan kinerja perusahaan semakin baik, kerena tingkat pengembalian (return) semakin besar (Husnan, 1998).

Laporan perkembangan syariah bank Indonesia 2008 menginformasikan bahwa kondisi bank syariah masih tetap positif terutama jika dilihat dari Financing to Deposit Ratio (FDR) terus meningkat dibanding tahun sebelumnya, bahkan angka penyaluran kredit bank syariah mencapai $104 \%$ (Laporan perkembangan Perbankan Syariah BI, 2008). Melihat kembali kajian penelitian terdahulu bahwa semakin tinggi pembiayaan yang disalurkan bank, maka semakin tinggi pula profit yang akan didapatkan oleh bank.

Tujuan penelitian yang akan diperoleh dalam penelitian ini diantaranya: untuk menganalisis kondisi Financing to Deposit Ratio (FDR) perbankan syariah di Indonesia, untuk menganalisis profitabilitas perbankan syariah di Indonesia, dan untuk menganalisis pengaruh Financing to Deposit Ratio (FDR) terhadap profitabilitas perbankan syariah di Indonesia.

\section{B. LANDASAN TEORI}

Bank syariah menjalankan kegiatan usahanya berdasarkan prinsip syariah dan menjauhi praktik riba, untuk diisi dengan kegiatan investasi atas dasar bagi hasil dari pembiayaan perdagangan. Industri perbankan syariah merupakan bagian dari sistem perbankan nasional yang mempunyai peranan penting dalam perekonomian. Peranan perbankan syariah secara khusus antara lain sebagai perekat nasionalisme baru, artinya menjadi fasilitator jaringan usaha ekonomi kerakyatan, memberdayakan ekonomi umat, mendorong penurunan spekulasi di pasar keuangan, mendorong pemerataan pendapatan, dan peningkatan efisiensi mobilitas dana ${ }^{3}$.

Bank Islam atau yang disebut dengan Bank syariah adalah bank yang beroperasi dengan tidak mengandalkan pada bunga. Bank syariah merupakan lembaga keuangan perbankan yang operasional dan produknya dikembangkan berlandaskan pada Al-Qur'an dan Hadist Nabi SAW. Dengan kata lain Bank Umum Syariah adalah bank yang melakukan kegiatan usaha atau beroperasi berdasarkan prinsip syariah dan tidak mengandalkan pada bunga dalam memberikan pembiayaan dan jasa-jasa lainnya dalam lalu lintas pembayaran ${ }^{4}$.

Menurut Dahlan Siamat (1995), rasio profitabilitas digunakan untuk mengukur efektifitas bank dalam memperoleh laba. Disamping dapat dijadikan sebagai ukuran kesehatan keuangan, rasio-rasio profitabilitas ini sangat penting untuk diamati mengingat keuntungan yang memadai diperlukan untuk mempertahankan arus sumber-sumber modal. Teknik analisis profitabilitas ini melibatkan hubungan antara pos-pos tertentu dalam laporan perhitungan laba rugi untuk memperoleh ukuran-ukuran yang dapat digunakan sebagai indikator untuk menilai efisiensi dan kemampuan bank memperoleh laba. Oleh karena itu teknik analisis ini disebut juga dengan analisis laporan laba rugi.

Kinerja perbankan dapat diukur dengan menggunakan rata-rata tingkat bunga pinjaman, rata-rata tingkat bunga simpanan, dan profitabilitas perbankan. Lebih lanjut lagi dalam penelitiannya menyatakan bahwa tingkat bunga simpanan merupakan ukuran kinerja yang lemah dan menimbulkan masalah, sehingga dalam penelitiannya disimpulkan bahwa profitabilitas merupakan indikator yang paling tepat untuk mengukur kinerja suatu bank ${ }^{5}$.

Muhammad, Bank Syari'ah Problem, dan Prospek Perkembangan di Indonesia, (Yogyakarta: Graha Ilmu, 2005), h. 16.

4 Muhammad, Bank Syari'ah Problem, dan Prospek Perkembangan di Indonesia, (Yogyakarta: Graha Ilmu, 2005), h. 5-7.

5 Sofriza Syofyan, "Pengaruh Struktur Pasar terhadap Kinerja Perbankan di Indonesia“, Media Riset Bisnis \& Manajemen, Vol. 2, No. 3, Desember, 2002. 
Untuk mengevaluasi kondisi keuangan dan kinerja suatu perusahaan, analisa keuangan membutuhkan suatu ukuran. Ukuran yang sering dipergunakan dalam hal ini adalah rasio atau indeks yang dihubungkan dua data keuangan. Ukuran profitabilitas yang digunakan adalah Return on Equity (ROE) untuk perusahaan pada umumnya dan Return on Asset (ROA) pada industri perbankan. Return on Asset (ROA) memfokuskan kemampuan perusahaan untuk memperoleh earning dalam operasi perusahaan, sedangkan Return on Equity (hanya mengukur return yang diperoleh dari invesatsi pemilik perusahaan dalam bisnis tersebut ${ }^{6}$.

Profitabilitas bank merupakan suatu kemampuan bank dalam menghasilkan laba. Kemampuan ini dilakukan dalam suatu periode. Bank yang sehat adalah bank yang diukur secara profitabilitas atau rentabilitas yang terus meningkat di atas standar yang ditetapkan.

Menurut Selamet Riyadi (2006:155) rasio profitabilitas adalah:

"Rasio profitabilitas adalah perbandingan laba (setelah pajak) dengan modal (modal inti) atau laba (sebelum pajak) dengan total asset yang dimiliki bank pada periode tertentu".

Agar hasil perhitungan rasio mendekati pada kondisi yang sebenarnya (real), maka posisi modal atau assets dihitung secara rata-rata selama periode tersebut.

Rentabilitas atau Profitabilitas bank adalah suatu kemampuan bank untuk memperoleh laba yang dinyatakan dalam persentase ${ }^{7}$.

Profitabilitas atau rentabilitas bank adalah alat untuk menganalisis atau mengukur tingkat efisiensi usaha dan profitabilitas yang dicapai oleh bank yang bersangkutan ${ }^{8}$. Profitabilitas atau sering disebut juga dengan rentabilitas menunjukkan tidak hanya jumlah kuantitas dan trend earning tetapi juga faktor-faktor yang mempengaruhi ketersediaan dan kualitas earning. Keberhasilan bank didasarkan pada penilaian kuantitatif terhadap rentabilitas atau profitabilitas bank yang diukur dengan dua rasio yang bobot sama. Bank Indonesia menilai kondisi profitabilitas perbankan di Indonesia didasarkan pada dua indikator yaitu sebagai berikut ${ }^{9}$ :

1. Return on Asset (ROA) atau tingkat pengembalian asset, dan

2. Rasio Biaya Operasional terhadap Pendapatan Operasional (BOPO).

Suatu bank dapat dimasukkan ke dalam klasifikasi sehat apabila:

a. Rasio tingkat pengembalian atau Return on Asset (ROA) mencapai sekurang-kurangnya $1,2 \%$,

b. Rasio biaya operasional terhadap pendapatan operasional tidak melebihi $93,5 \%$.

Menurut Selamet Riyadi (2006:155-156) rasio profitabilitas digolongkan menjadi :

1) Return On Equity (ROE) adalah rasio profitabilitas yang menunjukkan perbandingan antara laba (setelah pajak) dengan modal (modal inti) bank, rasio ini menunjukkan tingkat \% (persentase) yang dapat dihasilkan.

2) Return on Asset (ROA) adalah rasio profitabilitas yang menunjukkan perbandingan antara laba (sebelum pajak) dengan total asset bank, rasio ini menunjukkan tingkat efisiensi pengelolaan asset yang dilakukan oleh bank yang bersangkutan.

Pengertian Return on Asset (ROA) sebagai berikut:

"Return on Asset (ROA) adalah salah satu rasio yang digunakan untuk mengukur kemampuan manajemen bank dalam memperoleh keuntungan (laba) secara keseluruhan".

Rasio profitabilitas ini sekaligus menggambarkan efisiensi kinerja bank yang bersangkutan. Return on Asset (ROA) sangat penting, karena rasio ini mengutamakan nilai profitabilitas suatu bank yang diukur dengan asset produktif yang dananya sebagian besar berasal dari Dana Pihak Ketiga (DPK). Semakin besar Return on Asset (ROA) suatu bank

\footnotetext{
Dahlan Siamat, Manajemen Lembaga Keuangan Edisi 2, (Jakarta: Lembaga Penerbit FEUI, 2002).

Malayu S.P. Hasibuan, Dasar-Dasar Perbankan, (Jakarta: PT. Bumi Aksara, 2007).

Lukman Dendawijaya, Manajemen Perbankan, (Jakarta: Ghalia Indonesia, 2005), h. 118.

Malayu S.P. Hasibuan, Dasar-Dasar Perbankan, (Jakarta: PT. Bumi Aksara, 2007), h. 100.
} 
maka semakin besar pula tingkat keuntungan yang dicapai bank tersebut, dan semakin baik pula posisi bank tersebut dari segi penggunaan asset.

Return on Asset (ROA) merupakan perbandingan antara laba sebelum pajak dengan total aset dalam suatu periode, rumus yang digunakan untuk mencari Return on Asset (ROA) adalah sebagai berikut (Husnan, 1998):

$$
R O A=\frac{\text { Laba Sebelum Pajak }}{\text { Total Asset }} \times 100
$$

Menurut Bank Indonesia, penilaian aspek likuiditas mencerminkan kemampuan bank untuk mengelola tingkat likuiditas yang memadai untuk memenuhi kewajibannya secara tepat waktu dan untuk memenuhi kebutuhan yang lain. Disamping itu bank juga harus dapat menjamin kegiatan dikelola secara efisien dalam arti bahwa bank dapat menekan biaya pengelolaan likuiditas yang tinggi serta setiap saat bank dapat melikuidasi assetnya secara cepat dengan kerugian yang minimal ${ }^{10}$.

Peraturan Bank Indonesia menyatakan bahwa kemampuan likuiditas bank dapat diproksikan dengan Loan to Deposit Ratio (LDR) yaitu perbandingan antara pembiayaan dengan Dana Pihak Ketiga (DPK). Rasio ini digunakan untuk menilai likuiditas suatu bank yang dengan cara membagi jumlah pembiayaan yang diberikan oleh bank terhadap Dana Pihak Ketiga (DPK).

Loan to Deposit Ratio (LDR) merupakan rasio yang mengukur kemampuan bank untuk memenuhi kewajiban keuangan yang harus segera dipenuhi. Kewajiban tersebut berupa call money yang harus dipenuhi pada saat adanya kewajiban kliring, dimana pemenuhannya dilakukan dari aktiva lancar yang dimiliki perusahaan ${ }^{11}$.

Loan to Deposit Ratio (LDR) menunjukkan kemampuan bank di dalam menyediakan dana kepada debiturnya dengan modal yang dimiliki oleh bank maupun dana yang dikumpulkan dari masyarakat (Achmad dan Kusumo, 2003). Sedangkan menurut Dendawijaya (2005) Loan to Deposit Ratio (LDR) menyatakan seberapa jauh kemampuan bank dalam membayar kembali penarikan dana yang dilakukan deposan dengan mengandalkan kredit yang diberikan sebagai sumber likuiditasnya. Jika bank dapat menyalurkan seluruh dana yang dihimpun memang akan menguntungkan, namun hal ini terkait risiko apabila sewaktu-waktu pemilik dana menarik dananya atau pemakai dana tidak dapat mengembalikan dana yang dipinjamnya ${ }^{12}$. Werdaningtyas, (2002), dalam penelitiannya menunjukkan bahwa Loan to Deposit Ratio (LDR) berpengaruh negatif terhadap profitabilitas. Jika kita telaah lebih jauh, profitabilitas merupakan kemampuan suatu perusahaan (dalam hal ini bank) dalam mencetak laba. Rasio keuangan yang dipakai untuk mengukur profitabilitas adalah Return on Asset (ROA). Dalam penelitiannya dijelaskan bahwa Loan to Deposit Ratio (LDR) berpengaruh negatif tehadap Return on Asset (ROA). Return on Asset (ROA) disebabkan oleh peningkatan dalam pemberian kredit ataupun penarikan dana oleh masyarakat yang berdampak makin rendahnya likuiditas bank. Hal ini berdampak terhadap kepercayaan masyarakat yang pada akhirnya menyebabkan penurunan profitabilitas yang ditandai dengan menurunnya Return on Asset (ROA) ${ }^{13}$.

Meskipun demikian ada beberapa penelitian yang menyatakan bahwa Loan to Deposit Ratio (LDR) berpengaruh positif terhadap Return on Asset (ROA). Seperti penelitian yang dilakukan oleh Suyono (2005), yang menyatakan bahwa Loan to Deposit Ratio (LDR)

10 Surat Edaran Bank Indonesia No 6/73/Intern DPNP tanggal 24 Desember 2004. Perihal Pedoman Sistem Penilaian Tingkat Kesehatan Bank Umum (CAMELS Rating). Jakarta: Bank Indonesia.

11 Sinta Sudarini, Penggunaan Rasio Keuangan dalam Memprediksi Laba Masa yang Akan Datang, (Jurnal Akuntansi dan Manajemen, Vol. XVI No. 3 Desember, 2005), h. 195-207.

12 Lukman Dendawijaya, Manajemen Perbankan, (Jakarta: Ghalia Indonesia, 2005).

13 Hesti Werdaningtyas, Faktor yang Mempengaruhi Profitabilitas Bank Take Over Pramerger di Indonesia, (Jurnal Manajemen Indonesia), Vol. 1, No. 2, 2002. 
berpengaruh signifikan positif terhadap Return on Asset (ROA). Hal ini sejalan dengan penelitian yang dilakukan oleh Usman, (2003), dimana Loan to Deposit Ratio (LDR) berpengaruh positif terhadap laba bank. Karena laba merupakan komponen yang membentuk Return on Asset (ROA), maka dapat disimpulkan bahwa secara tidak langsung Loan to Deposit Ratio (LDR) juga berpengaruh positif terhadap Return on Asset (ROA). Kemudian Haryati, (2001), menyatakan bahwa tingkat likuiditas bank mempunyai pengaruh terhadap kinerja keuangan yang diproksikan dengan Return on Asset (ROA). Menurut Sugianto, et.al, (2002), Loan to Deposit Ratio (LDR) dapat digunakan sebagai indikator untuk mengukur tingkat kesehatan bank.

Rasio ini menyatakan seberapa jauh kemampuan bank dalam membayar kembali penarikan dana yang dilakukan deposan dengan mengandalkan kredit/pembiayaan yang diberikan sebagai likuiditasnya. Semakin tinggi rasio tersebut memberikan indikasi semakin rendahnya kemampuan likuiditas bank yang bersangkutan. Hal ini disebabkan karena jumlah dana yang diperlukan untuk pembiayaan menjadi semakin besar.

Para praktisi perbankan menyepakati bahwa batas aman dari Loan to Deposit Ratio (LDR) adalah sekitar 80\%. Namun batas toleransi berkisar antara 85\% - 100\%. Namun oleh Bank Indonesia, suatu bank masih dianggap sehat jika Loan to Deposit Ratio (LDR) nya masih dibawah $110 \%$.

Dalam perbankan syariah tidak dikenal istilah kredit (loan) namun pembiayaan atau financing ${ }^{14}$ Pada umunya konsep yang sama ditunjukkan pada bank syariah dalam mengukur likuiditas yaitu dengan menggunakan Financing to Deposit Ratio (FDR) (Muhammad, 2009). Financing to Deposit Ratio (FDR) yaitu seberapa besar Dana Pihak Ketiga (DPK) bank syariah dilepaskan untuk pembiayaan ${ }^{15}$.

Financing to Deposit Ratio (FDR) merupakan rasio yang digunakan untuk mengukur likuiditas suatu bank dalam membayar kembali penarikan dana yang dilakukan deposan dengan mengandalkan pembiayaan yang diberikan sebagai sumber likuiditasnya, yaitu dengan cara membagi jumlah pembiayaan yang diberikan oleh bank terhadap Dana Pihak Ketiga (DPK). Semakin tinggi Financing to Deposit Ratio (FDR) maka semakin tinggi dana yang disalurkan ke Dana Pihak Ketiga (DPK). Dengan penyaluran Dana Pihak Ketiga (DPK) yang besar maka pendapatan bank Return on Asset (ROA) akan semakin meningkat, sehingga Financing to Deposit Ratio (FDR) berpengaruh positif terhadap Return on Asset (ROA).

Standar yang digunakan Bank Indonesia untuk rasio Financing to Deposit Ratio (FDR) adalah $80 \%$ hingga $110 \%$. Jika angka rasio Financing to Deposit Ratio (FDR) suatu bank berada pada angka dibawah $80 \%$ (misalkan 60\%), maka dapat disimpulkan bahwa bank tersebut hanya dapat menyalurkan sebesar $60 \%$ dari seluruh dana yang berhasil dihimpun. Karena fungsi utama dari bank adalah sebagai intermediasi (perantara) antara pihak yang kelebihan dana dengan pihak yang kekurangan dana, maka dengan rasio Financing to Deposit Ratio (FDR) 60\% berarti 40\% dari seluruh dana yang dihimpun tidak tersalurkan kepada pihak yang membutuhkan, sehingga dapat dikatakan bahwa bank tersebut tidak menjalankan fungsinya dengan baik. Kemudian jika rasio Financing to Deposit Ratio (FDR) bank mencapai lebih dari $110 \%$, berarti total pembiayaan yang diberikan bank tersebut melebihi dana yang dihimpun. Oleh karena dana yang dihimpun dari masyarakat sedikit, maka bank dalam hal ini juga dapat dikatakan tidak menjalankan fungsinya sebagai pihak intermediasi (perantara) dengan baik. Semakin tinggi Financing to Deposit Ratio (FDR) menunjukkan semakin riskan kondisi likuiditas bank, sebaliknya semakin rendah Financing to Deposit

\footnotetext{
14 M. Syafi'i Antonio, Bank Syariah dari Teori ke Praktik, (Jakarta: Gema Insani Press dan Tazkia Cendekia, 2001), h. 70.

15 Muhammad, Bank Syari'ah Problem, dan Prospek Perkembangan di Indonesia, (Yogyakarta: Graha Ilmu, 2005), h. 265.
} 
Ratio (FDR) menunjukkan kurangnya efektifitas bank dalam menyalurkan pembiayaan. Jika rasio Financing to Deposit Ratio (FDR) bank berada pada standar yang ditetapkan oleh Bank Indonesia, maka laba yang diperoleh oleh bank tersebut akan meningkat (dengan asumsi bank tersebut mampu menyalurkan pembiayaannya dengan efektif).

Rasio ini dirumuskan sebagai berikut:

$\mathrm{FDR}=\frac{\text { Jumlah Dana y ang diberikan }}{\text { Total Dana Pihak Ketiga }}$ X100\%

Penelitian mengenai rasio keuangan bank di Indonesia telah dilakukan oleh beberapa peneliti. Hasil penelitian terdahulu terdapat beberapa variabel yang berpengaruh terhadap profitabilitas bank, namun tidak konsisten hasilnya.

Penelitian tentang Analisa Faktor-Faktor yang Mempengaruhi Profitabilitas Bank Take Over (BTO) Pramerger di Indonesia selama tahun 1990-1998. Penelitian dilakukan untuk mengetahui pengaruh, CAR, LDR, dan variabel dummy, pangsa aset, pangsa dana, pangsa kredit terhadap profitabilitas dan untuk mengetahui variabel yang dominan pengaruhnya terhadap profitabilitas BTO di Indonesia ${ }^{16}$.

Hasil penelitian menunjukkan variabel pangsa pasar yang diukur dengan pangsa aset, pangsa dana dan pangsa kredit tidak mempunyai pengaruh yang signifikan terhadap profitabilitas secara partial. CAR secara signifikan berpengaruh positif terhadap profitabilitas, sedangkan LDR secara signifikan berpengaruh negatif terhadap profitabilitas. Faktor yang dominan mempengaruhi profitabilitas BTO berturut-turut adalah CAR, LDR, dan kondisi perekonomian.

Analisis Pengaruh Faktor Makroekonomi, Pangsa Pasar dan Karakteristik Bank Terhadap Profitabilitas Bank Syariah (Studi Pada Bank Syariah Periode 2005-2008). Tujuan penelitian adalah untuk menganalisis pengaruh kondisi ekonomi makro yang diproksi dengan inflasi dan GDP, pengaruh karakteristik bank yang diproksi dari FDR, CAR, NPF, BOPO dan SIZE , dan pengaruh pangsa pasar yang diproksi dengan pembiayaan bank syariah terhadap profitabilitas bank syariah yang diproksikan dengan ROA $^{17}$.

Hasil penelitian menunjukkan bahwa variabel Inflasi dan GDP, tidak berpengaruh terhadap ROA. Pangsa Pembiayaan, CAR, FDR berpengaruh signifikan positif terhadap ROA perbankan, sedangkan BOPO, NPF, dan SIZE berpengaruh signifikan negatif terhadap ROA Bank Syariah.

Diah Aristya (2010), Analisis Pengaruh Ukuran Perusahaan, Kecukupan Modal, Kualitas Aktiva Produktif (KAP) dan Likuiditas Terhadap Kinerja Keuangan Bank Syariah periode 2005-2009. Tujuan penelitian untuk mengetahui pengaruh Ukuran Perusahaan, Kecukupan Modal, Kualitas aktiva Produktif dan Likuiditas terhadap ROA. Hasil penelitian menunjukkan bahwa variabel SIZE berpegaruh positif terhadap ROA. CAR tidak berpengaruh terhadap ROA, KAP dan LIQ berpengaruh signifikan signifikan negatif terhadap ROA Bank Syariah.

Shinta Tri Furi (2005) dalam penelitiannya tentang Faktor-Faktor yang Mempengaruhi Profitabilitas Sektor Perbankan di Indonesia tahun 2001-2003. Penelitian dilakukan untuk mengetahui pengaruh LDR, GWM, CAR, NPL, BOPO, dan NIM terhadap Profitabilitas. Hasil penelitian menyatakan bahwa LDR, GWM, CAR, NPL, BOPO, dan NIM secara simultan berpengaruh signifikan terhadap profitabilitas bank. Namun secara parsial LDR dan

${ }^{16}$ Werdaningtyas, Hesti, Faktor yang Mempengaruhi Profitabilitas Bank Take Over Pramerger di Indonesia, (Jurnal Manajemen Indonesia, Vol. 1, No. 2, 2002).

17 Adi Stiawan, Analisis Pengaruh Faktor Makroekonomi, Pangsa Pasar Dan Karakteristik Bank Terhadap Profitabilitas Bank Syariah (Studi Pada Bank Syariah Periode 2005-2008), Tesis Program Studi Magister Manajemen Program Pascasarjana, Universitas Diponegoro, 2009. diakses dari http://www.eprints.undip.ac.id, acceessed 10 Maret 2011. 
GWM tidak berpengaruh signifikan terhadap profitabilitas bank. CAR, BOPO secara signifikan berpengaruh negatif terhadap profitabilitas, serta NPL, NIM secara signifikan berpengaruh positif terhadap profitabilitas.

Yuliani (2007) meneliti tentang Hubungan Efisiensi Operasional dengan Kinerja Profitabilitas pada Sektor Perbankan yang Go Publik di Bursa Efek Jakarta. Penelitian dilakukan untuk mengetahui seberapa besar kontribusi tingkat MSDN, BOPO, CAR, dan LDR terhadap besarnya ROA baik secara simultan maupun secara parsial. Hasil penelitian menunjukkan bahwa variabel BOPO dan CAR berpengaruh signifikan terhadap ROA, sedangkan variabel yang lainnya tidak berpengaruh terhadap ROA.

Siti Nurkhosidah (2010) meneliti tentang Pengaruh Variabel Non Performing Financing, Penyisihan Penghapusan Aktiva Produktif, Financing To Deposit Ratio, Biaya Operasional Per Pendapatan Operasional Terhadap Profitabilitas Pada Bank Syariah periode 2005-2007. Tujuan penelitian ini adalah untuk mengetahui apakah terdapat pengaruh yang signifikan dan bagaimana pengaruhnya NPF, PPAP, FDR dan BOPO terhadap profitabilitas bank syariah yang dinyatakan dengan Return on Asset (ROA).

Secara teoritis, ada banyak faktor yang mempengaruhi profitabilitas. Rasio likuiditas yang diproksikan dengan Financing to Deposit Ratio (FDR) dijadikan variabel yang mempengaruhi Return on Asset (ROA) berkaitan dengan adanya pertentangan kepentingan (conflict of interest) antara likuiditas dengan profitabilitas. Jila ingin mempertahankan posisi likuiditas dengan memperbesar cadangan kas, maka bank tidak akan memakai seluruh loanable funds yang ada karena sebagian dikembalikan lagi dalam bentuk cadangan tunai (cash reserve), ini berarti usaha pencapaian profitabilitas akan berkurang. Sebaliknya jika bank ingin mempertinggi profitabilitas, maka dengan cash reserve untuk likuiditas terpakai oleh bisnis bank, sehingga posisi likuiditas akan turun (Sinungan, 2000: 98). Jika rasio ini meningkat dalam batas tertentu maka akan semakin banyak dana yang disalurkan dalam bentuk pembiayaan, sehingga akan meningkatkan laba bank, dengan asumsi bank menyalurkan dananya untuk pembiayaan yang efektif. Dengan meningkatnya laba, maka Return on Asset (ROA) juga akan meningkat, karena laba merupakan komponen yang membentuk Return on Asset (ROA) (Budi Ponco, 2008, dalam Iwan Setiawan, 2009).

Berdasarkan kajian teori dan bukti empiris maka hipotesis yang diajukan dalam penelitian ini adalah:

"Financing to Deposit Ratio (FDR) berpengaruh positif dan signifikan terhadap profitabilitas Return on Asset (ROA) pada perbankan syariah di Indonesia”.

\section{Kerangka Pemikiran}

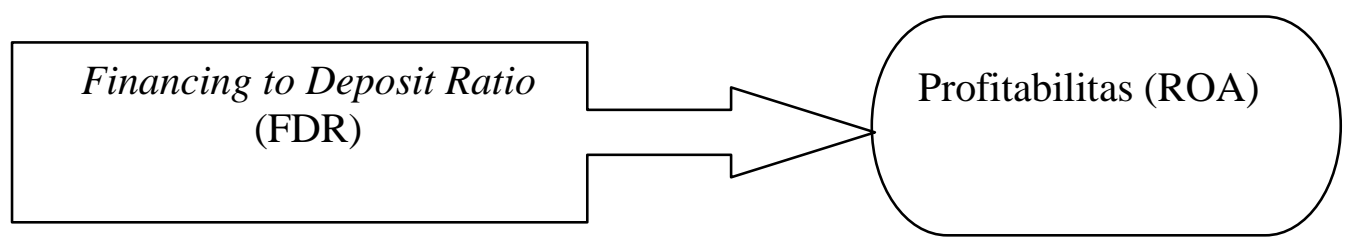

\section{METODE PENELITIAN}

Metode dalam penelitian ini adalah metode analisis deskriptif kuantitatif, yaitu hasil penelitian yang kemudian diolah dan dianalisis untuk diambil kesimpulannya, artinya penelitian yang dilakukan adalah penelitian yang menekankan analisisnya pada data-data numeric (angka), dengan menggunakan metode penelitian ini akan diketahui hubungan yang signifikan antara variabel yang diteliti, sehingga menghasilkan kesimpulan yang akan memperjelas gambaran mengenai objek yang diteliti. Penelitian ini menggunakan pendekatan kuantitatif yang bersifat ex post facto yakni mempelajari fakta-fakta yang sudah ada. Prosesnya berupa mendeskripsikan dengan cara menginterpretasi data yang telah diolah. 
Penelitian ini dilanjutkan dengan studi kepustakaan (library research) untuk mencari kesinambungan antara teori yang ada dengan kenyataan berdasarkan hasil penelitian, termasuk implikasinya.

Variabel independent atau variabel bebas adalah variabel yang mempengaruhi variabel lainnya dan merupakan variabel yang menjadi sebab perubahan atau timbulnya variabel dependent (terikat). Data yang menjadi variabel bebas (Variabel X) adalah Financing to Deposit Ratio (FDR).

Variabel dependent atau variabel terikat yaitu variabel yang dipengaruhi atau yang menjadi akibat, karena adanya variabel bebas. Data yang menjadi variabel terikat (Variabel Y) adalah profitabilitas.

Dalam penelitian ini, penulis menggunakan data sekunder. Data sekunder merupakan data yang diperoleh si peneliti secara tidak langsung melalui media perantara (diperoleh dan dicatat oleh pihak lain). Data sekunder ini meliputi dokumen, catatan, laporan keuangan dan tulisan yang terkait dengan fokus penelitian.

Data didapatkan dengan pengumpulan data sekunder yang berasal dari Statistik Perbankan Syariah Indonesia yang diterbitkan oleh Bank Indonesia melalui website www.bi.go.id sebagai situs resmi Bank Indonesia.

Sedangkan metode pengumpulan data adalah metode dokumentasi. Metode dokumentasi merupakan usaha mengumpulkan data yang dilaksanakan dengan jalan mencari data yang berupa laporan keuangan, surat kabar, majalah, dan dokumen penunjang lainnya. Dalam hal ini data yang dikumpulkan terkait fokus penelitian ini, bersumber dari data sekunder yang telah dipublikasikan oleh Bank Indonesia melalui website www.bi.go.id.

Studi pustaka adalah pengumpulan data dengan cara mempelajari dan memahami bukubuku yang mempunyai hubungan dengan bank syariah, Financing to Deposit Ratio (FDR), profitabilitas serta pembahasan tentang keuangan perbankan seperti jurnal, media massa dan hasil penelitian yang diperoleh dari berbagai sumber.

Penelitian ini mengambil populasi seluruh bank syariah di Indonesia dari bulan Januari tahun 2008 sampai dengan per bulan Desember 2010 (Studi Rasio Keuangan pada BUS dan UUS periode 2008-2010). Jumlah keseluruhan bank syariah yang ada adalah 34 bank meliputi 11 Bank Umum Syariah (BUS), 23 Unit Usaha Syariah (UUS).

Metode analisis yang digunakan adalah metode analisis deskriptif kuantitatif yaitu datadata yang diperoleh kemudian dikumpulkan dan dianalisis berdasarkan metode yang telah ditetapkan dengan tujuan untuk mengetahui ada tidaknya pengaruh antara Financing to Deposit Ratio (FDR) terhadap profitabilitas pada perbankan syariah di Indonesia. Berdasarkan uraian di atas maka pemilihan tes statitik yang akan dilakukan adalah regresi sederhana.

Analisis regresi adalah suatu teknik yang digunakan untuk membangun suatu persamaan yang menghubungkan antara variabel X Financing to Deposit Ratio (FDR) dan variabel $\mathrm{Y}$ profitabilitas. Persamaan yang menyatakan bentuk hubungan antara variabel independent $(\mathrm{X})$ dan variabel dependent $(\mathrm{Y})$ disebut juga persamaan regresi.

Persamaan regresi linier sederhana adalah:

$$
\begin{aligned}
& \mathbf{Y}=\mathbf{a}+\mathbf{B x} \\
& \text { Dimana : } \\
& \mathrm{Y}=\text { Profitabilitas } \\
& \text { a } \quad \text { Suatu bilangan konstanta yang merupakan nilai } \mathrm{Y} \text { apabila } \mathrm{X}=0 \\
& \mathrm{~b} \quad=\text { Koefisien regresi }
\end{aligned}
$$


$\mathrm{X} \quad=$ Financing to Deposit Ratio $(\mathrm{FDR})$

Untuk mendapatkan a dan b digunakan rumus sebagai berikut:

$$
\begin{aligned}
& \mathrm{a}=\frac{\left(\sum \mathrm{Y}\right)\left(\sum \mathrm{X}^{2}\right)-\left(\sum \mathrm{X}\right)\left(\sum \mathrm{XY}\right)}{\mathrm{n}\left(\sum \mathrm{X}^{2}\right)-\left(\sum \mathrm{X}\right)^{2}} \\
& \mathrm{~b}=\frac{\mathrm{n}\left(\sum \mathrm{XY}\right) \cdot\left(\sum \mathrm{X}\right)-\left(\sum \mathrm{Y}\right)}{\mathrm{n}\left(\sum \mathrm{X}^{2}\right)-\left(\sum \mathrm{X}\right)^{2}} \\
& \mathrm{Y} \quad=\text { Profitabilitas } \\
& \mathrm{X} \quad=\text { Financing to Deposit Ratio (FDR) } \\
& \mathrm{n} \quad=\text { Jumlah data sampel } \\
& \mathrm{a} \quad=\text { Tingkat profitabilitas jika Financing to Deposit Ratio (FDR) tidak ada } \\
& \mathrm{b} \quad=\text { Kecenderungan perubahan tingkat Profitabilitas akibat penerimaan } \\
& \quad \text { Financing to Deposit Ratio (FDR) }
\end{aligned}
$$

Pengujian hipotesis dilakukan untuk mengevaluasi adanya pengaruh Financing to Deposit Ratio (FDR) terhadap profitabilitas. Tahapan penetapan uji hipotesis ini dimulai dengan penetapan hipotesis nol, pemilihan tes statistik dan penghimpunan nilai statistik serta penetapan tingkat signifikansi.

\section{Hipotesis:}

Uji-t akan digunakan untuk menguji signifikansi konstanta dan variabel penelitian.

Ho : $\rho=0$, artinya Financing to Deposit Ratio (FDR) sebagai variabel $\mathrm{X}$ tidak berpengaruh terhadap profitabilitas sebagai variabel $\mathrm{Y}$.

$H_{1}: \rho \neq 0$, artinya Financing to Deposit Ratio (FDR) sebagai variabel X berpengaruh terhadap profitabilitas sebagai variabel Y.

Formula untuk menguji hipotesis tersebut, maka data yang diperoleh dapat dianalisis dengan menggunakan rumus menurut Sugiyono (2004:292), sebagai berikut:

$$
\begin{aligned}
& \text { Dimana : } \\
& \mathrm{t}=\frac{\mathrm{r} \sqrt{\mathrm{n}-2}}{\sqrt{1-\mathrm{r}^{2}}} \\
& \mathrm{r}^{2} \quad=\text { Koefisien korelasi } \\
& \mathrm{n} \quad=\text { Jumlah sampel }
\end{aligned}
$$

Parameter uji untuk menarik kesimpulan dari hipotesis di atas dilakukan dengan kriteria uji tolak $\mathrm{H}_{0}$ jika $\mathrm{t}$ hitung $<\mathrm{t}$ tabel dengan derajat kebebasan $\mathrm{dk}=\mathrm{n}-2$ dan taraf signifikansi $\alpha=0,05(5 \%)$.

Kriteria penolakan dan penerimaan hipotesis $\mathrm{H}_{0}$ adalah sebagai berikut :

- Jika $\mathrm{t}$ tabel $<\mathrm{t}$ hitung, maka $\mathrm{H}_{0}$ ada pada daerah penolakan, berarti $\mathrm{H}_{\mathrm{a}}$ diterima atau ada pengaruh. 
- Jika $\mathrm{t}$ tabel $>\mathrm{t}$ hitung, maka $\mathrm{H}_{0}$ ada pada daerah penerimaan, berarti $\mathrm{H}_{\mathrm{a}}$ ditolak atau tidak ada pengaruh.

\section{Gambar \\ Uji Dua Pihak Daerah Penerimaan dan Penolakan Hipotesis}

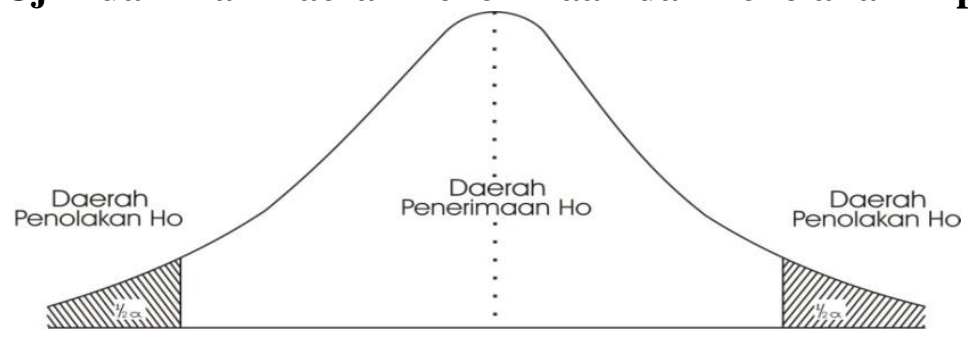

HASIL PENELITIAN

\section{Deskripsi variabel}

Deskripsi Financing to Deposit Ratio (FDR)

Financing to Deposit Ratio (FDR) merupakan rasio yang digunakan untuk mengukur likuiditas suatu bank dalam membayar kembali penarikan dana yang dilakukan deposan dengan mengandalkan pembiayaan yang diberikan sebagai sumber likuiditasnya, yaitu dengan cara membagi jumlah pembiayaan yang diberikan oleh bank terhadap Dana Pihak Ketiga (DPK).

\section{Gambar}

Perkembangan Rata-rata FDR 2008 - 2010

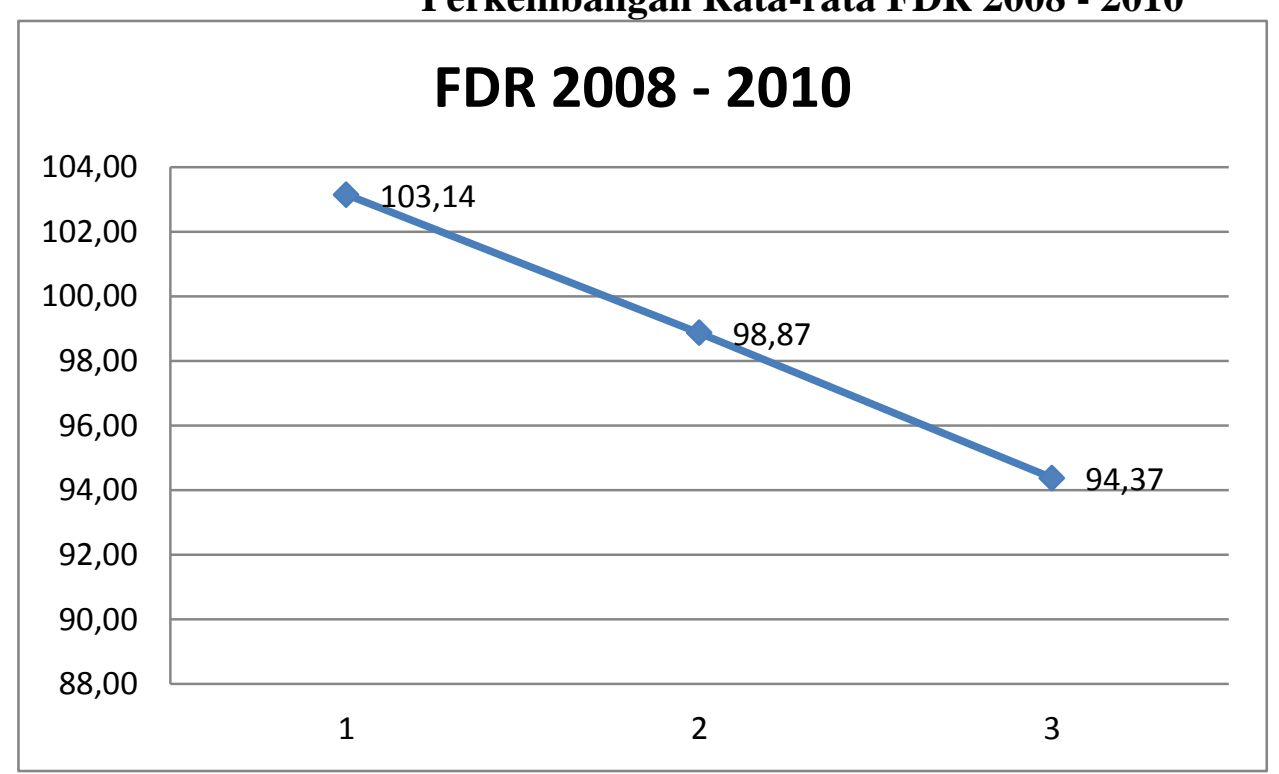

Sumber : BI, Statistik Perbankan Syariah, diolah (2011)

Rasio pembiayaan yang disalurkan dengan besarnya Dana Pihak Ketiga (DPK) yang dinyatakan dengan nilai Financing to Deposit Ratio (FDR) bank syariah memiliki rata-rata Financing to Deposit Ratio (FDR) sebesar 103.65\% sepanjang tahun 2008, 89.70\% di tahun 2009 dan sebesar $94.37 \%$ di tahun 2010. Berbeda dengan tahun-tahun sesudahnya, pada tahun 2008 Financing to Deposit Ratio (FDR) perbankan syariah lebih dari $100 \%$. Tingginya tingkat Financing to Deposit Ratio (FDR) tersebut karena pembiayaan yang disalurkan selama bulan Maret - November 2008 lebih besar dari Dana Pihak ketiga (DPK). 


\section{Gambar \\ Perkembangan FDR Tahun 2008}

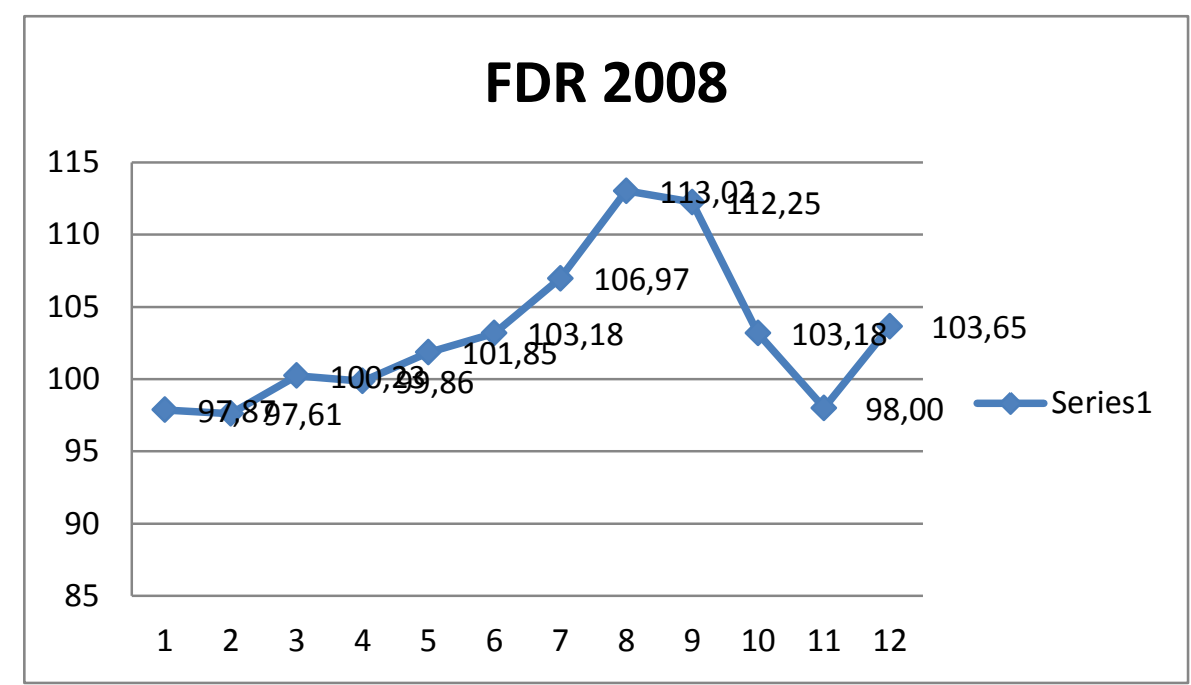

Sumber : BI, Statistik Perbankan Syariah, diolah (2011)

Perkembangan Financing to Deposit Ratio (FDR) selama tahun 2008 mengalami tren kenaikan mulai dari bulan Maret 2008 dan mencapai puncaknya di bulan Agustus yaitu sebesar $113.02 \%$. Financing to Deposit Ratio (FDR) terendah terjadi di bulan September yaitu sebesar $98.00 \%$, sementara secara rata-rata sepanjang tahun 2008, Financing to Deposit Ratio (FDR) adalah sebesar $103.65 \%$.

\section{Gambar}

Perkembangan FDR tahun 2009

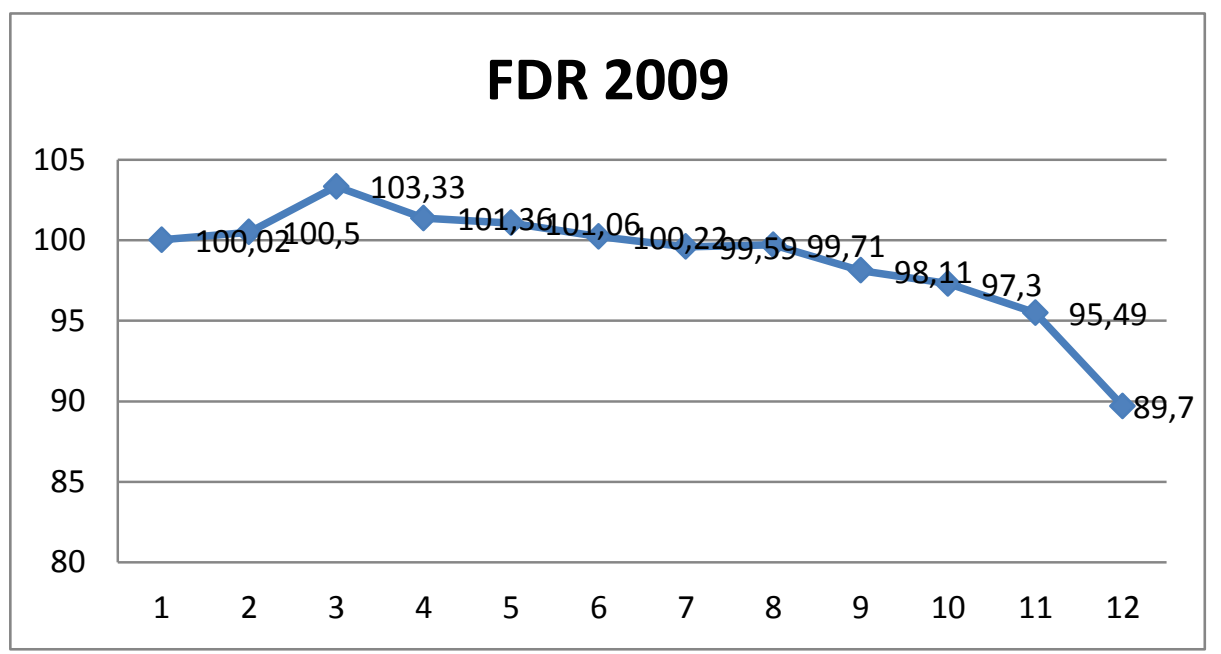

Sumber : BI, Statistik Perbankan Syariah 2010, diolah (2011)

Perkembangan Financing to Deposit Ratio (FDR) selama tahun 2009 mengalami tren penurunan mulai dari bulan April 2009 sampai dengan Desember 2009. Titik terendah FDR terjadi di bulan Desember 2009 yaitu sebesar 89.7\% sementara tertinggi sebesar 103.33\% yang terjadi di bulan Maret 2009. Sepanjang tahun 2009, besaran ratarata FDR adalah $98.87 \%$. 


\section{Gambar \\ Perkembangan FDR Tahun 2010}

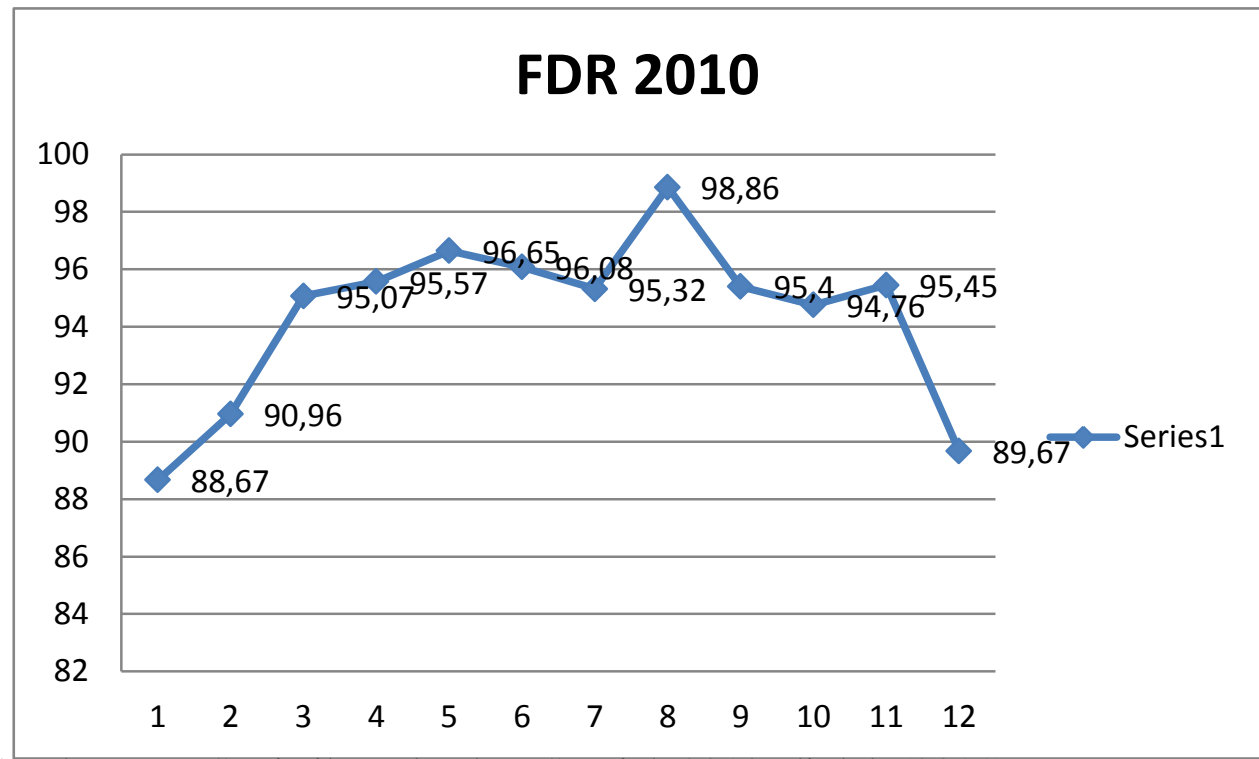

Sumber : BI, Statistik Perbankan Syariah 2010, diolah (2011)

Perkembangan FDR selama tahun 2010 terjadi secara dinamis yaitu mengalamai tren kenaikan dari bulan Januari 2010, dan mencapai titik puncaknya di bulan Agustus 2010 sebesar $98.86 \%$. Selanjutnya terjadi tren penurunan sampai dengan akhir tahun 2010. Secara rata-rata, FDR perbankan syariah di tahun 2010 adalah sebesar 94.37\%.

Deskripsi Return on Asset (ROA)

Return on Asset (ROA) merupakan salah satu rasio profitabilitas yang digunakan untuk mengukur efektivitas perusahaan dalam menghasilkan keuntungan dengan memanfaatkan total yang dimilikinya. Berdasarkan ketentuan Bank Indonesia, maka standar Return on Asset (ROA) yang baik adalah sekitar 1,5\%. Semakin besar Return on Asset (ROA) menunjukkan kinerja perusahaan semakin baik, karena return semakin besar.

\section{Gambar \\ Perkembangan ROA Tahun 2008-2010}

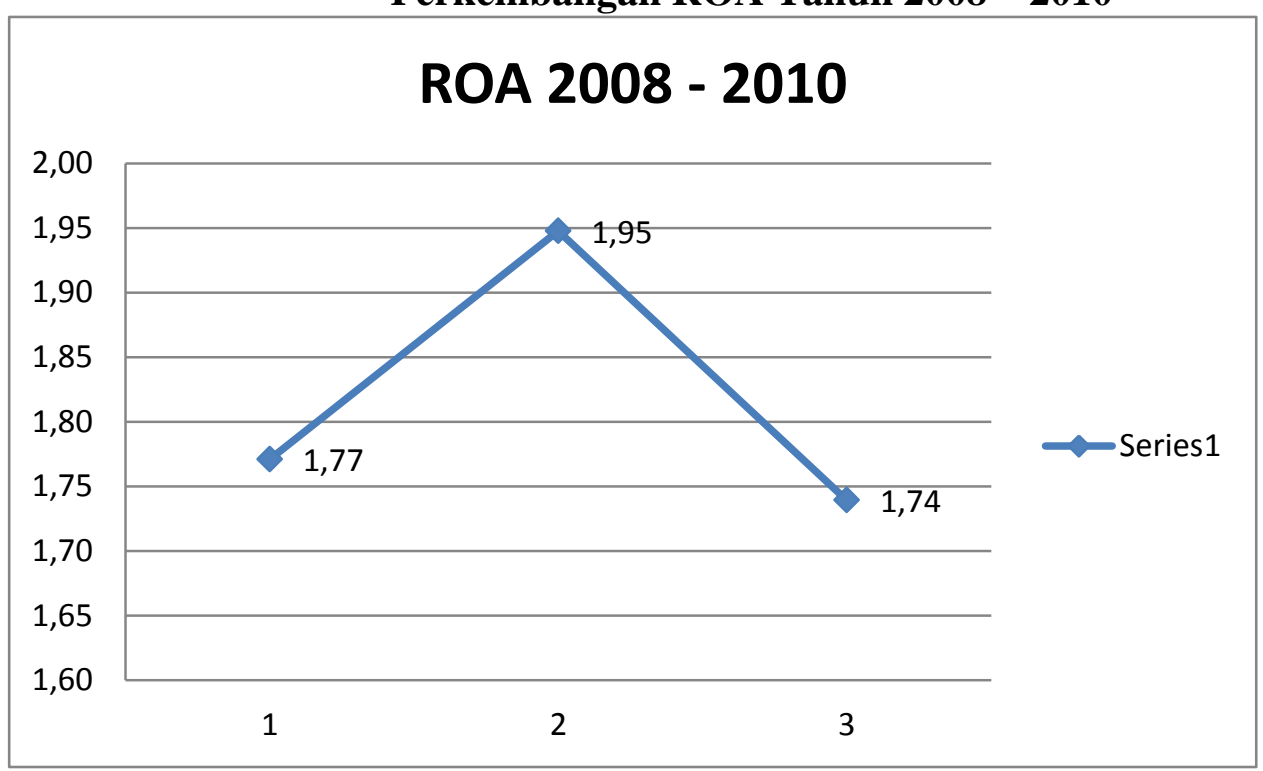

Sumber : BI, Statistik Perbankan Syariah 2010, diolah (2011) 
Peningkatan Dana Pihak Ketiga (DPK) yang tidak diimbangi penyaluran Pembiayaan yang Diberikan (PYD) berdampak pada penurunan profitabilitas bank syariah. Return on Asset (ROA) di tahun 2008 secara rata-rata tercatat sebesar 1.77\%, 1.98\% di tahun 2009 dan $1.74 \%$ di tahun 2010.

\section{Gambar}

Perkembangan ROA Tahun 2010

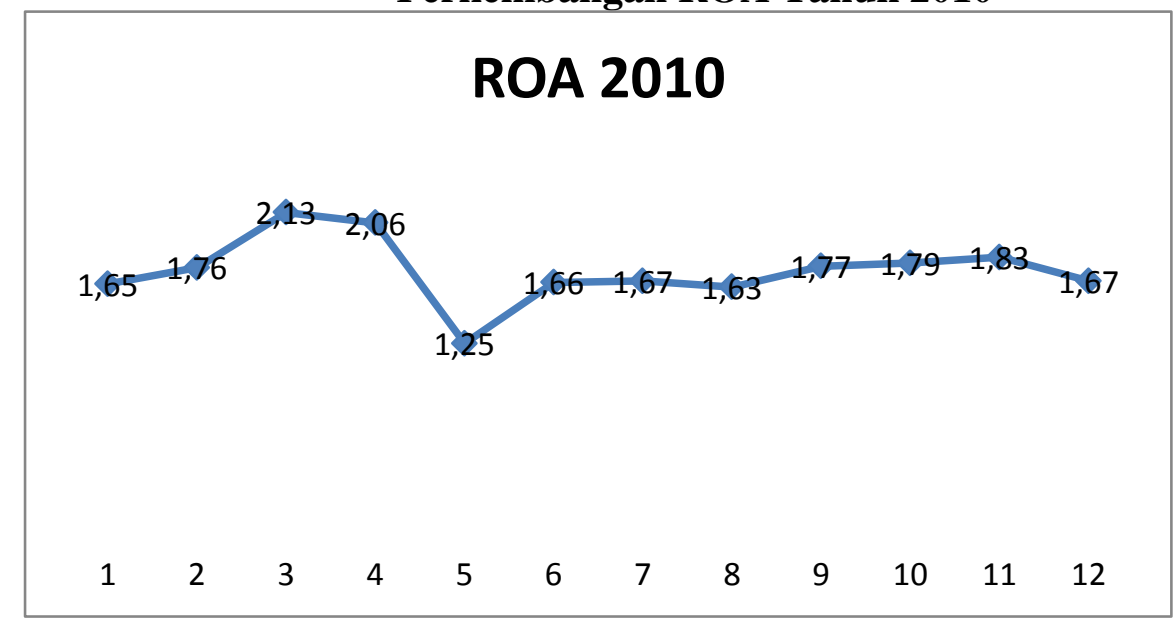

Sumber : BI, Statistik Perbankan Syariah 2010, diolah (2011)

Perkembangan Return on Asset (ROA) selama tahun 2010 menunjukkan rata-rata sebesar 1.74. ROA tertinggi terjadi di bulan Maret yaitu sebesar 2.13\%, sementara terendah terjadi di bulan Mei sebesar 1.25.

Setelah gambaran mengenai variabel Financing to Deposit Ratio (FDR) maupun Return on Asset (ROA) maka selanjutnya akan dibahas mengenai tren kenaikan atau penurunan dari data empiris yang diperoleh. Tren adalah suatu gerakan kecenderungan naik atau turun dalam jangka panjang yang diperoleh dari rata-rata perubahan dari waktu ke wakti dan nilainya cukup rata atau mulus (smooth).

Tren meningkat disebut tren positif dan tren menurun disebut tren negatif (Suharyadi dan Purwanto, 2007:180). Dalam hal ini akan dilakukan analisis untuk melihat tren masing-masing variabel penelitian.

Metode yang digunakan adalah metode kuadrat terkecil diperoleh dengan menentukan garis tren yang mempunyai jumlah kecil mempunyai jumlah terkecil dari kuadrat selisih data asli dengan data pada garis tren. Persamaan yang digunakan adalah :

$\mathrm{Y}=\mathrm{a}+\mathrm{bX}$

Dimana:

Y : nilai tren

a : nilai konstanta

b : nilai kemiringan yaitu tambahan nilai $\mathrm{Y}$ apabila $\mathrm{X}$ bertambah

$\mathrm{X} \quad$ : nilai perolehan periode

Untuk memperoleh nilai a dan $\mathrm{b}$ menggunakan rumus berikut :

$\mathrm{a}=\sum \mathrm{Y} / \mathrm{n}$

$\mathrm{b}=\sum \mathrm{XY} / \sum \mathrm{X}^{2}$

Data X (periode) adalah data tahunan Financing to Deposit Ratio (FDR) dan Return on Asset (ROA) periode tahun 2005 sampai dengan 2010, sehingga jumlah data yang digunakan adalah sebanyak 6 observasi. 


\section{Tabel}

Tabel Bantuan Perhitungan Tren FDR

\begin{tabular}{|c|c|c|c|c|}
\hline Tahun & $Y$ & $\mathrm{X}$ & $\mathrm{Y} * \mathrm{X}$ & $\mathrm{X}^{2}$ \\
\hline 2005 & 97.76 & -2.5 & -244.4 & 6.25 \\
\hline 2006 & 98.90 & -1.5 & -148.35 & 2.25 \\
\hline 2007 & 99.76 & -0.5 & -49.88 & 0.25 \\
\hline 2008 & 103.65 & 0.5 & 51.825 & 0.25 \\
\hline 2009 & 89.70 & 1.5 & 134.55 & 2.25 \\
\hline 2010 & 89.67 & 2.5 & 224.175 & 6.25 \\
\hline & 579.44 & & -32.08 & 17.50 \\
\hline
\end{tabular}

nilai $\mathrm{a}=\sum \mathrm{Y} / \mathrm{n}=579.44 / 6=96.57$

nilai $b=\sum X Y / \sum X^{2}=-32.08 / 17.50=-.1 .83$

Berdasarkan hasil perhitungan di atas, persamaan tren yang diperoleh adalah $\mathrm{Y}$ $=96.57-1.83$ X. Hasil persamaan ini menunjukkan bahwa tren Financing to Deposit Ratio (FDR) adalah tren negatif dimana ada kecenderungan penurunan setiap tahunnya. Berdasarkan hasil perhitungan ini dapat diramalkan besaran Financing to Deposit Ratio (FDR) yang akan diperoleh pada tahun 2011 dan 2012 dengan kode $\mathrm{X}=$ 3.5, dan $\mathrm{X}=4.5$ adalah:

Tahun 2011

$\mathrm{Y}=96.57-1.83(3.5)=90.157$

Tahun 2012

$\mathrm{Y}=96.57-1.83(4.5)=88.32$

Tabel

Tabel Bantuan Perhitungan Tren ROA

\begin{tabular}{|l|l|l|l|l|}
\hline Tahun & \multicolumn{1}{|c|}{$\mathrm{Y}$} & \multicolumn{1}{c|}{$\mathrm{X}$} & \multicolumn{1}{c|}{$\mathrm{Y}^{*} \mathrm{X}$} & \multicolumn{1}{c|}{$\mathrm{X} 2$} \\
\hline 2005 & 1.35 & -2.5 & -3.375 & 6.25 \\
\hline 2006 & 1.55 & -1.5 & -2.325 & 2.25 \\
\hline 2007 & 2.07 & -0.5 & -1.035 & 0.25 \\
\hline 2008 & 1.42 & 0.5 & 0.71 & 0.25 \\
\hline 2009 & 1.48 & 1.5 & 2.22 & 2.25 \\
\hline 2010 & 1.67 & 2.5 & 4.175 & 6.25 \\
\hline & 9.54 & & 0.37 & 17.50 \\
\hline
\end{tabular}

Sumber : BI, Statistik Perbankan Syariah 2010, diolah (2011)

nilai $\mathrm{a}=\sum \mathrm{Y} / \mathrm{n}=9.54 / 6=1.59$

nilai $b=\sum X Y / \sum X^{2}=0.37 / 17.50=0.021$

Persamaan yang dibentuk dari hasil perhitungan ini adalah $\quad \mathrm{Y}=1.59+0.021 \mathrm{X}$. Terlihat bahwa tren yang terjadi adalah tren positif dimana ada indikasi semakin meningkatnya Return on Asset (ROA) dimasa depan. Berdasarkan persamaan ini dapat diprediksi besaran Return on Asset (ROA) di tahun 2011 dan 2012 dengan $\mathrm{X}=3.5$ dan $\mathrm{X}=$ 4.5 .

Tahun 2011:

$\mathrm{Y}=1.59+0.021(3.5)=1.66$

Tahun 2012

$\mathrm{Y}=1.59+0.021(4.5)=1.69$ 


\section{Analisis Regresi}

Uji Asumsi Normalitas

Uji normalitas bertujuan untuk menguji apakah dalam model regresi, variabel dependen dan variabel independen mempunyai distribusi normal atau tidak. Model regresi yang baik adalah yang memiliki distribusi data normal/mendekati normal. Pengujian normalitas ini dapat dilakukan melalui analisis grafik dan analisis statistik (Ghozali, 2009:147-151).

Deteksi normalitas data dapat dilakukan melalui analisis statistik yang salah satunya dapat dilihat melalui uji statistik Jarque-Bera (JB). Data disebut normal apabila nilai JB lebih rendah atau sama dengan nilai kritis tabel Chi- Square dan probabilitasnya probabilitasnya > 0.05, maka model dinyatakan normal (Widarjono, 2009:54).

\section{Gambar}

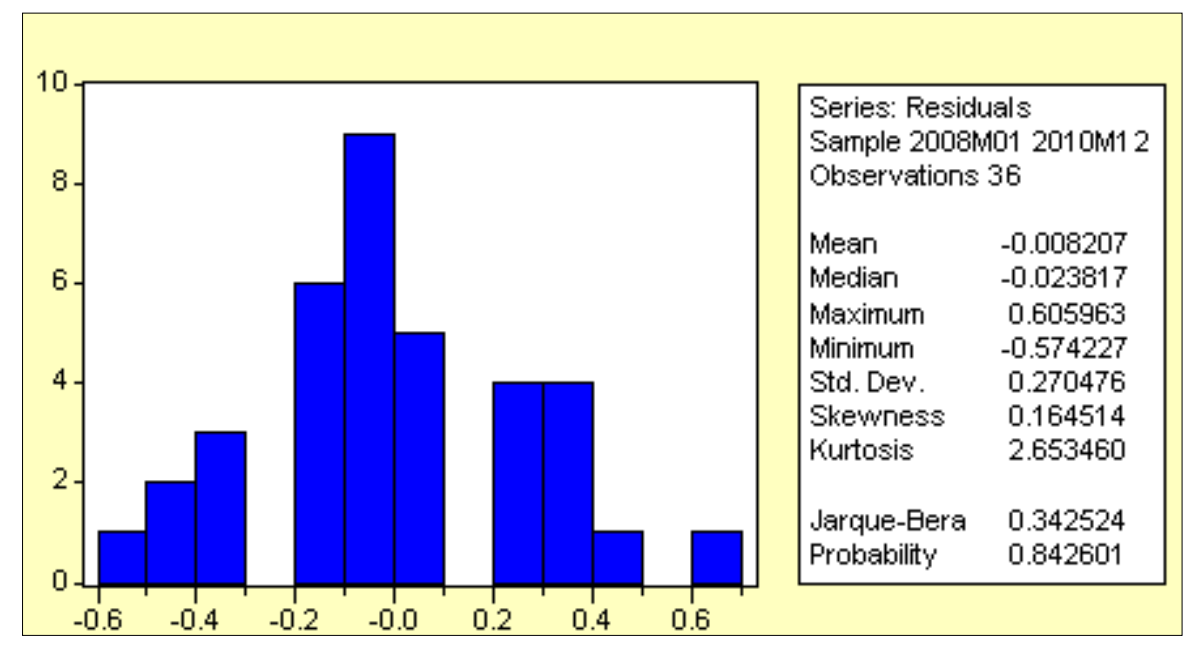

\section{Uji Normalitas}

Sumber : data sekunder, diolah dengan EVIEWS 5

Melalui bentuk grafik terlihat bahwa bentuk histogram sepertinya didistribusikan secara simetris sehingga residualnya diduga berdistribusi normal. Hasil uji normalitas dengan melihat nilai probabilitas dari Jargue-Bera (JB) menunjukkan nilai JB sebesar 0.342 dengan probabilitas 0.842 . Nilai probabilitas lebih besar dibanding nilai 0.05 , sehingga dapat disimpulkan model berdistribusi normal, atau dengan kata lain, residual regresi Financing to Deposit Ratio (FDR) ke Return on Asset (ROA) mempunyai distribusi normal dengan probabilitas sebesar 0.842 (84.20\%).

Analisis Regresi dan Pengujian Hipotesis

Bentuk model persamaan regresi yang digunakan dalam penelitian ini untuk mengetahui besarnya pengaruh variabel independent yaitu:

$$
\begin{aligned}
R O A= & \alpha+\mathrm{b} \text { FDR }+\mathrm{e} \\
& \text { Dimana }: \\
& \text { ROA }=\text { Return on Asset } \\
& \text { FDR }=\text { Financing to Deposit Ratio }
\end{aligned}
$$

Untuk menjawab masalah, mencapai tujuan dan pembuktian hipotesis serta untuk mengetahui apakah variabel independen secara parsial berpengaruh signifikan (nyata) terhadap variabel dependen, maka perlu dilakukan uji t. Analisis regresi pada penelitian ini menggunakan program statistik EVIEWS versi 5. 
Tabel

Hasil Regresi

\begin{tabular}{|cclll}
\hline \hline \multicolumn{1}{c}{ Variable } & Coefficient & Std. Error & t-Statistic & Prob. \\
\hline \hline C & 1.682296 & 0.189245 & 8.889526 & 0.0000 \\
FDR & 0.001469 & 0.001970 & 0.745314 & 0.4612 \\
\hline \hline R-squared & 0.016075 & Mean dependent var & 1.819167 \\
Adjusted R-squared & -0.012864 & S.D. dependent var & 0.272506 \\
S.E. of regression & 0.274253 & Akaike info criterion & 0.304419 \\
Sum squared resid & 2.557294 & Schwarz criterion & 0.392392 \\
Log likelihood & -3.479539 & F-statistic & 0.555493 \\
Durbin-Watson stat & 0.928103 & Prob(F-statistic) & 0.461203 \\
\hline
\end{tabular}

Koefisien determinasi $\left(\mathrm{R}^{2}\right)$ pada intinya mengukur seberapa jauh kemampuan model dalam menerangkan variasi dependennya. Nilai R2 yang mendekati satu berarti variabel-variabel independennya memberikan hampir semua informasi yang dibutuhkan untuk memprediksi variasi variabel dependen (Ghozali, 2009). Nilai $\mathrm{R}^{2}$ yang mendekati 1 (satu) berarti variabel-variabel independen memberikan hampir semua informasi yang dibutuhkan untuk memprediksi variabel dependen.

Koefisien determinasi $\left(\mathrm{R}^{2}\right)$ dari hasil estimasi persamaan adalah sebesar 0,016, yaitu berarti perubahan pada variabel hanya mampu menjelaskan variabel dependen sebesar 1.6 persen, sedangkan sisanya dijelaskan oleh variabel lain yang tidak termasuk dalam model.

$\mathrm{ROA}=1.682295884+0.001468509356^{*} \mathrm{FDR}$

\section{- Pengujian Hipotesis}

Hipotesis diajukan menyatakan bahwa Financing to Deposit Ratio (FDR) berpengaruh positif terhadap terhadap Return on Asset (ROA). Berdasarkan hasil uji t yang dilakukan diperoleh $t$ hitung sebesar 0.745 dan $t$ tabel sebesar $2.032(\mathrm{df}=36-2=34$, alpha 5\%). Karena nilai t hitung lebih kecil dari t tabel $0.745<2.032$ maka Ho diterima, artinya FDR tidak berpengaruh signifikan terhadap Return on Asset (ROA). Uji t juga konsisten dengan probabilitas yang menghasilkan nilai 0.461 (>0.05) yang menunjukkan bahwa tidak adanya pengaruh signifikan Financing to Deposit Ratio (FDR) terhadap Return on Asset (ROA).

Hipotesis secara parsial dengan $\mathrm{Uji}-\mathrm{t}$ tersebut dapat digambarkan sebagai berikut:

\section{Gambar}

Pengujian Hipotesis melalui t Test

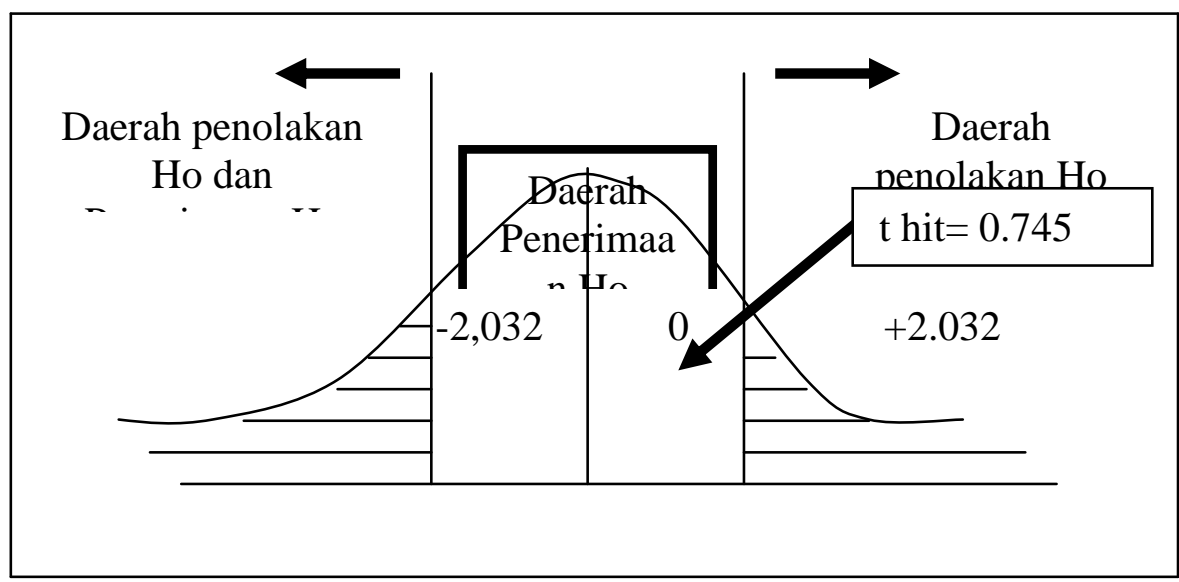


Sumber : data sekunder, diolah dengan EVIEWS 5

Berdasarkan gambar di atas diketahui bahwa nilai t hitung yang dihasilkan berada di wilayah arsiran dengan nilai positif 0.745 dan berada di wilayah penerimaan Ho, lebih kecil dari nilai t tabel (2.032) sehingga membuktikan penerimaan Ho dan penolakan terhadap Ha, atau secara parsial tidak terdapat pengaruh positif Financing to Deposit Ratio (FDR) terhadap Return on Asset (ROA).

\section{PEMBAHASAN}

Hasil analisis regresi menunjukkan tidak adanya pengaruh signfikan Financing to Deposit Ratio (FDR) terhadap Return on Asset (ROA). Besaran t hitung adalah 0.745 jauh dibawah t tabel 2.032. Hasil penelitian ini berbeda dengan penelitian Adi Stiawan (2009), namun mendukung penelitian Siti Nurkhosidah (2010) dan Yuliani (2007), menunjukkan hasil yang tidak berpengaruhnya Financing to Deposit Ratio (FDR) terhadap profitabilitas bank.

Rasio Financing to Deposit Ratio (FDR) digunakan untuk mengukur likuiditas suatu bank dengan cara membagi jumlah kredit yang diberikan oleh bank terhadap Dana Pihak Ketiga (DPK). Semakin tinggi Financing to Deposit Ratio (FDR) maka semakin tinggi dana yang disalurkan ke Dana Pihak Ketiga (DPK).

Selama tiga tahun pengamatan, rata-rata Financing to Deposit Ratio (FDR) adalah sebesar $98.79 \%$, sementara Return on Asset (ROA) adalah sebesar 1.82\%. Standar deviasi Financing to Deposit Ratio (FDR) sebesar 5.34 menunjukkan variabilitas Financing to Deposit Ratio (FDR) dalam tiga tahun pengamatan, sementara standar deviasi Return on Asset (ROA) adalah sebesar 0.27. Ini menunjukkan bahwa variasi yang terjadi pada FDR tidak sepenuhnya mampu mempengaruhi variabilitas Return on Asset (ROA), hal ini mungkin diakibatkan adanya faktor lain yang lebih mempengaruhi Return on Asset (ROA) seperti CAR, NPF, BOPO atau kondisi makro ekonomi (GDP).

Tabel

Deskriptif Statistik Variabel

\begin{tabular}{|l|l|l|}
\hline & FDR & ROA \\
\hline Mean & 98.79 & 1.82 \\
\hline Maximum & 113.02 & 2.44 \\
\hline Minimum & 88.67 & 1.25 \\
\hline Std. Dev & 5.34 & 0.27 \\
\hline
\end{tabular}

Dengan nilai rata-rata $98.79 \%$ menunjukkan bahwa penyaluran pembiayaan syariah dari bank-bank syariah cukup baik artinya penyaluran pembiayaan lebih besar daripada dana yang disimpan oleh nasabah. Sehingga dengan hal ini bank di satu sisi akan memperoleh bagi hasil yang cukup besar dari debitur daripada bagi hasil yang diberikan kepada nasabah yang menyimpan dananya di bank syariah. Namun tentunya ini juga mengandung resiko pembiayaan yang cukup besar karena semakin besarnya dana pembiayaan yang disalurkan. Pada bank syariah istilah Non Performing Loan (NPL) diganti Non Performing Finance (NPF) karena dalam syariah menggunakan prinsip pembiayaan. Non Performing Finance (NPF) merupakan tingkat risiko yang dihadapi bank. Non Performing Finance (NPF) adalah jumlah pembiayaan yang bermasalah dan kemungkinan tidak dapat ditagih. 
Berdasarkan statistik perbankan syariah yang dikeluarkan oleh tahun 2010, diperoleh data mengenai Non Performing Finance (NPF) dalam periode tiga tahun terakhir yaitu $1.42 \%$ (2008), 4.01\% (2009) dan 4.13\% (2010). Indikasi meningkatnya Non Performing Financing (NPF) ini menunjukkan bahwa terjadi sedikit kenaikan tingkat risiko pada pembiayaan yang bermasalah. Kondisi ini juga diduga menjadi penyebab tidak signifikannya pengaruh Financing to Deposit Ratio (FDR) terhadap Return on Asset (ROA).

\section{E. KESIMPULAN}

Hasil analisis dan pembahasan yang telah dijelaskan di bab terdahulu, maka kesimpulan dari penelitian ini adalah:

a. Financing to Deposit Ratio (FDR) bank syariah memiliki rata-rata sebesar $103.65 \%$ sepanjang tahun 2008, 89.70\% di tahun 2009 dan sebesar $94.37 \%$ di tahun 2010 . Secara keseluruhan, rata-rata Financing to Deposit Ratio (FDR) dalam periode tiga tahun pengamatan adalah sebesar $98.79 \%$.

b. Return on Asset (ROA) merupakan salah satu rasio profitabilitas yang digunakan untuk mengukur efektivitas perusahaan dalam menghasilkan keuntungan dengan memanfaatkan total yang dimilikinya. Berdasarkan deskripsi variabel diperoleh ratarata Return on Asset (ROA) di tahun 2008 sebesar 1.77\%, 1.98\% di tahun 2009 dan $1.74 \%$ di tahun 2010. Hasil ini menunjukkan bahwa rata-rata Return on Asset (ROA) dalam tiga tahun pengamatan masih berada di atas ketentuan Bank Indonesia yaitu standar Return on Asset (ROA) yang baik adalah sekitar 1,5\%.

c. Hasil analisis regresi menunjukkan tidak adanya pengaruh signfikan Financing to Deposit Ratio (FDR) terhadap Return on Asset (ROA). Besaran t hitung adalah 0.745 jauh dibawah $\mathrm{t}$ tabel 2.032. Hasil penelitian ini berbeda dengan penelitian Adi Setiawan (2009), namun mendukung penelitian Siti Nurkhosidah (2010) dan Yuliani (2007), menunjukkan hasil yang tidak berpengaruh signifikan terhadap profitabilitas bank.

d. Penelitian mendatang hendaknya menambah berbagai rasio keuangan seperti CAR, $\mathrm{NPF}, \mathrm{BOPO}$, maupun variabel lain seperti GDP, inflasi, dan pangsa pasar pembiayaan secara umum, manajemen laba, pembagian deviden, jenis pembiayaan dan sebagainya. Penelitian lanjutan juga disarankan untuk menggunakan pendekatan multivariate dimana banyak faktor yang akan ditetapkan sebagai variabel bebas sehingga diperoleh gambaran yang lebih objektif mengenai faktor apa saja yang dapat mempengaruhi profitabilitas. 


\section{DAFTAR PUSTAKA}

Al-Quran dan Hadits.

A. Djazuli dan Yudi Janwari. 2002. Lembaga-Lembaga Perekonomian Umat; Sebuah Pengenalan. Jakarta: PT RajaGrafindo Persada.

Ali, Masyhud. 2006. Manajemen Risiko : Strategi Perbankan dan Dunia Usaha Menghadapi Tantangan Globalisasi Bisnis. Jakarta: Rajawali Pers.

2004. Asset Liability Management : Menyiasati Risiko Pasar dan Risiko

Operasional, Jakarta: PT. Gramedia.

Antonio, Muhammad Syafi'i. 2001. Bank Syariah dari Teori ke Praktik. Jakarta: Gema Insani Press dan Tazkia Cendekia.

Arbi, Syarif. 2002. Mengenal Bank dan Lembaga Keuangan Non Bank. Jakarta: Djambatan. Arifin, Zainul. 2000. Memahami Bank Syariah. Jakarta: Alvabet.

Arikunto, Suharsimi. 2006. Prosedur Penelitian Suatu Pendekatan Praktik. Cet. Ke-13. Jakarta: PT. Rineka Cipta.

Bank Indonesia. 1999. Petunjuk Pelaksanaan Pembukaan Kantor Bank Syari'ah. Jakarta: Bank Indonesia.

2002. Cetak Biru Pengembangan Perbankan Syariah Nasional Periode 2002-2011. Jakarta: Bank Indonesia.

2009. Statistik Perbankan Syariah Juni 2009. Jakarta: Direktorat Perbankan Syariah.

Dendawijaya, Lukman. 2005. Manajemen Perbankan. Jakarta: Ghalia Indonesia.

Ghazali, Imam. 2001. Aplikasi Analisis Multivariate Dengan Program SPSS. Semarang: BP Universitas Diponegoro.

Ghazali, Imam. 2006. Aplikasi Analisis Multivariate dengan Program SPSS. Semarang. Badan Penerbit UNDIP.

Gujarati, Damodar N. 2006. Dasar-dasar Ekonometrika. Edisi Ketiga. Jakarta: Erlangga.

Hasibuan, Malayu S.P. 2007. Dasar-Dasar Perbankan. Jakarta: PT. Bumi Aksara.

Hassan dan Bashir. 2002. Determinants of Islamic Banking Profitabilitas. International Journal. ERF Paper.

Sudarsono, Heri. 2003. Bank dan Lembaga Keuangan Syariah. Yogyakarta: Ekonisia.

Husnan, Suad. 2002. Dasar-Dasar Manajemen Keuangan. Edisi Ketiga. Yogyakarta: UPP AMP YKPN.

Indriantoro, Nur dan Bambang Supomo. 2002. Metode Penelitian Bisnis. Edisi Pertama. Cetakan Pertama. Yogyakarta: BPFE.

infobank No. 334 Januari 2007. Vol. XXIX hal. 4.

Karim, Adiwarman A. 2004. Bank Islam Analisis Fiqih dan Keuangan. Edisi Dua. Jakarta: PT RajaGrafindo Persada.

Kasmir. 2003. Manajemen Perbankan. Edisi 1. Jakarta: PT RajaGrafindo Persada.

2005. Bank dan Lembaga Keuangan Lain. Edisi 6. Jakarta: PT RajaGrafindo Persada.

Kuncoro, Mudrajad dan Suhardjono. 2002. Manajemen Perbankan Teori dan Aplikasinya. Yogyakarta: BPFE.

Meythi. 2005. Rasio Keuangan yang Paling Baik untuk Memprediksi Pertumbuhan Laba: Suatu Studi Empiris pada Perusahaan Manufaktur yang Terdaftar di Bursa Efek Jakarta. Jurnal Ekonomi dan Bisnis. Vol. XI, No. 2, September. 2005.

Muhammad Ghafur W. 2003. Pengaruh Tingkat Bagi Hasil, Suku Bunga dan Pendapatan Terhadap Simpanan Mudharabah: Studi kasus Bank Muamalat Indonesia (BMI). Jurnal Ekonomi Syariah Muamalah. Shariah Economic Forum UGM Yogyakarta. Volume 2, No. 2. 
Muhammad. 2005. Manajemen Bank Syariah. Yogyakarta: UUP AMPYKPN.

2005. Bank Syari'ah Problem, dan Prospek Perkembangan di Indonesia. Yogyakarta: Graha Ilmu.

Muljono, Teguh Pudjo. 1995. Analisa Laporan Keuangan Untuk Perbankan. Jakarta: Djambatan.

Nachrowi D.N dan Hardius Usman. 2006. Pendekatan Populer dan Praktis EKONOMETRIKA Untuk Analisis Ekonomi dan Keuangan. Jakarta: LP-FEUI.

Perwataatmadja, Karnaen A. dan M. Syafi'i Antonio. 1992. Apa dan Bagaimana Bank Syari'ah. Yogyakarta: Dana Bhakti Wakaf.

Rose, Peter S. 1995. Commercial Bank Management. Illinois: Irwin.

Sekaran, Uma. 2000. Research Method for Business : A Skill Building Approach. $3^{\text {rd }}$ Edition, New York: John Willey \& Sons Inc.

Siamat, Dahlan. 2002. Manajemen Lembaga Keuangan. Edisi 2. Jakarta: Lembaga Penerbit FEUI.

Sinungan, Muchdarsyah. 1987. Uang dan Bank. Cetakan I. Jakarta: Bina Aksara.

Sudarini, Sinta. 2005. Penggunaan Rasio Keuangan dalam Memprediksi Laba Masa yang Akan Datang. Jurnal Akuntansi dan Manajemen, Vol. XVI No. 3 Desember 2005.

Stiawan, Adi. 2009. Analisis Pengaruh Faktor Makroekonomi, Pangsa Pasar Dan Karakteristik Bank Terhadap Profitabilitas Bank Syariah (Studi Pada Bank Syariah Periode 2005-2008), Tesis Program Studi Magister Manajemen Program Pascasarjana, Universitas Diponegoro, diakses dari http://www.eprints.undip.ac.id, acceessed 10 Maret 2011.

Sudarsono, Heri. 2003. Bank Lembaga Keuangan Syariah : Deskripsi dan Ilustrasi. Yogyakarta: Ekonisia.

Sugiyono. 2007. Metode Penelitian Kuantitatif Kualitatif dan R \& D. Bandung: Alvabeta.

Sumitro, Warkum. 2004. Asas-asas Perbankan Islam \& Lembaga-lembaga Terkait (BAMUI, Takaful dan Pasar Modal Syari'ah) di Indonesia. Jakarta: PT RajaGrafindo Persada.

Supranto, Johanes. 2001. Statistik: Teori dan Aplikasi. Edisi ke-6 Jilid II. Cet. Ke-1. Jakarta: Erlangga.

Surat Edaran Bank Indonesia No 3/30 DPNP tangga 14 Desember 2001. Perihal Laporan Keuangan Publikasi Bank Umum kepada Bank Indonesia. Jakarta: Bank Indonesia.

Surat Edaran Bank Indonesia No 6/73/Intern DPNP tanggal 24 Desember 2004. Perihal Pedoman Sistem Penilaian Tingkat Kesehatan Bank Umum (CAMELS Rating). Jakarta: Bank Indonesia.

Syofyan, Sofriza. 2002. Pengaruh Struktur Pasar terhadap Kinerja Perbankan di Indonesia. Media Riset Bisnis \& Manajemen. Vol. 2, No. 3, Desember 2002.

Werdaningtyas, Hesti. 2002. Faktor yang Mempengaruhi Profitabilitas Bank Take Over Pramerger di Indonesia. Jurnal Manajemen Indonesia. Vol. 1, No. 2.

www.bi.go.id.

www.lontar.ui.ac.id accessed 23 Agustus 2011.

http://bisniskeuangan.kompas.com/read/2010/01/06/November 2009 Aset Bank Syariah Rp. 61.35.T), acceessed 22 April 2011.

http://elib.unikom.ac.id/files/pdf.

http://www.rmexpose.com.

http://www.xa.yimg.com, Pengaruh Pelaksanaan Office Channeling Terhadap Pertumbuhan Bank, acceessed 22 April 2011. 